\title{
Ethology of Proctacanthus gracilis Bromley, 1928 (Diptera: Asilidae) in Northeastern Florida, U.S.A.
}

\author{
D. Steve DENNIS
}

1105 Myrtle Wood Drive, St. Augustine, Florida 32086-4838, U.S.A., e-mail: dstevedennis@msn.com, ORCID ID: 0000-0002-4832-4026

\begin{abstract}
Proctacanthus gracilis Bromley, 1928 forages primarily from vegetation, capturing prey in flight, and immobilizing them in flight or on the ground. Identified prey is in eight insect orders (Coleoptera, Diptera, Hemiptera, Hymenoptera, Lepidoptera, Neuroptera, Odonata, and Orthoptera), with Othoptera making up $63.0 \%$. Mating occurs in the tail-to-tail position and oviposition is in the ground. This species exhibits a distinct daily rhythm of activity for feeding and mating. Grooming behavior resembles that described for other species of robber flies. Morphology, habitats and distribution in Florida, resting behavior, and predators and parasites also are discussed.
\end{abstract}

Key words: Behavior, robber flies, morphology, prey, Diptera, Asilidae.

Dennis, D. S. (2020). Ethology of Proctacanthus gracilis Bromley, 1928 (Diptera: Asilidae) in Northeastern Florida, U.S.A.. Journal of the Entomological Research Society, 22(3), 255-273. 


\section{INTRODUCTION}

Proctacanthus gracilis Bromley, 1928 is a Nearctic species with distribution in the southeastern United States in Alabama, Florida, Georgia, Mississippi, and South Carolina (Fisher \& Wilcox, 1997; Geller-Grimm, 2019). This paper provides detailed information on the ethology of this species in the Moses Creek Conservation Area (MCCA) in St. Augustine, St. Johns County, in Northeastern Florida, U.S.A. Information also is provided on morphological characteristics that distinguish $P$. gracilis from other species of Proctacanthus, in particular in the MCCA.

Proctacanthus gracilis is $23-34 \mathrm{~mm}$ in length and its body is reddish in ground color with a pale yellowish to yellowish-brown pruinescence (Fig. 1). The proboscis is slender and the mystax is white, sometimes with a few black setae above. The wings are nearly hyaline with a reddish tinge and veins, and extend to at least abdominal segment 6 . The legs are reddish with black bristles.

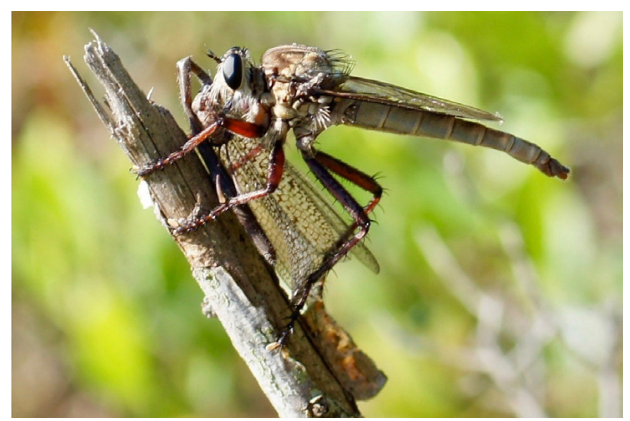

Fig. 1. Male Proctacanthus gracilis with adult ant lion prey (Photograph: D.S. Dennis, 29.07.2011, 10:47 AM).

\section{MATERIALS AND METHODS}

Records in the Florida State Collection of Arthropods (FSCA) indicate that $P$. gracilis occurs from about mid-May through early October in Florida. In the MCCA the majority of observations were made during June through August over nine field seasons: 02.06.2011-17.08.2011; 09.07.2012; 04.06.2013-15.08.2013; 26.05.2014-29.08.2014; 16.06.2015-24.07.2015; 23.05.16-28.07.2016; 07.07.2017-23.08.2017; 14.06.2018-24.07.2018; and 28.06.2019-06.08.2019. Some years had shorter periods of study because of inclement weather and low populations of flies.

The identification of $P$. gracilis was confirmed using Hine (1911) and the description in Bromley (1928), and comparing specimens with those in the FSCA. Most of the latter specimen identifications were by C.H. Martin $(1958,1960)$ and J. Wilcox $(1967$, 1979), and one by S.W. Bromley (1949). The identifications were confirmed by Riley Nelson (Brigham Young University, Provo, Utah in 1989) who has extensively studied species in the genus Proctacanthus.

The author studied $P$. gracilis when it was most abundant in mowed scrub vegetation communities in the MCCA. Observations involved an average of 3 individuals per 


\section{Ethology of Proctacanthus gracilis}

day, each for up to 5 hours and 55 minutes. Total number of hours of observations equaled approximately 112, not including the many hours searching for individuals or populations of $P$. gracilis to observe.

Proctacanthus gracilis was studied by the author sitting on the ground or standing and observing single flies for as long as possible in order to collect information on their various behaviors and diurnal activities. The author also slowly walked through a study area and observed the activities of a number of flies, primarily to collect prey and to locate mating pairs and ovipositing females.

Collected prey was placed in glass vials with a label indicating the sex of the predator, date, time, and location. The author sent prey that he could not identify to the U. S. Department of Agriculture, Agricultural Research Service, Systematic Entomology Laboratory (SEL), Beltsville, Maryland, U.S.A. for identification. Prior to shipment, prey was measured with a clear, plastic ruler to the nearest $0.5 \mathrm{~mm}$.

While in the field, a hand held Taylor thermometer and/or a Cooper-Atkins DPP400W Digital Thermometer were used to take air, surface and subsurface ground temperatures. A Dwyer Hand-Held Wind Meter measured wind speed.

\section{RESULTS AND DISCUSSION}

\section{Morphology}

Bromley (1928) described $P$. gracilis based on specimens from Georgia and indicated that they are $26.0-30.0 \mathrm{~mm}$ in length. The author measured 10 males and females from the MCCA and females range in size from 23.0-31.0 mm (average 27.4 $\mathrm{mm}$ ) in length, and males range from $24.0-30.0 \mathrm{~mm}$ (average $27.1 \mathrm{~mm}$ ) in length. The lengths of the specimens in the MCCA and the FSCA are similar, although two females in the latter were 33 and $34 \mathrm{~mm}$ long.

Bromley (1928) indicated that the hairs of the palpi, mystax, beard, and post-genae are "...nearly white with a very pale yellowish tinge." The mystax of some of the specimens from the MCCA and in the FSCA have a few black bristles/hairs above, and/or one to two black, subvibrissal (oral margin) bristles/hairs, one of which is usually smaller than the other. The postgenae bristles/hairs are pure white to a pale yellowish white.

Bromley (1928) described $P$. gracilis with a, "Thorax reddish in ground color... and covered.... with pale yellowish bloom....Ground color of abdomen reddish, but covered with pale yellowish bloom and fine pubescence."

The reddish brown ground color on the thorax is particularly prevalent anteriorly on either side of the dorsal stripes. This color often extends to the postpronotal lobe (postpronotum), mesothoracic spiracle, and anepisternum, which are partly to completely reddish brown. The scutellum also may be reddish brown.

The "bloom" or pruinescence, is yellowish to yellowish brown. In the field, when $P$. gracilis is in the sun and viewed from the side, some of their bodies look yellowish to 
yellowish green, in particular in front of the wings and ventrolaterally. Also, on some specimens in the MCCA and FSCA, the disc of the scutellum (in particular anteriorly) is silverish white and the sides of the thorax may be glistening yellowish-silverish white.

Hine (1911) did not describe in detail the markings [i.e., stripes (lines) and lateral spots] on the dorsum of the thorax of the sixteen species of Proctacanthus that he dealt with, but often called them, "...the usual markings..." For most of these species the thorax is dark and often a uniform color, and the stripes and spots are not clearly seen or are indistinct unless magnification is used (e.g., in the MCCA, P. fulviventris, $P$. heros, and $P$. rufus). At least the outlines of the stripes and spots of only a few species can be seen without magnification (e.g., in the MCCA, $P$. brevipennis, $P$. gracilis, and $P$. longus).

Bromley (1928) stated that the thorax of $P$. gracilis has a "...dark red median line and vittae..." The specimens in Florida usually have distinct median and paramedian stripes of the scutum and lateral spots (Fig. 2; terminology follows Geller-Grimm, 2020). The stripes are wider anteriorly and narrow posteriorly, with the posterior $1 / 4-1 / 3$ split. The median stripe is light red to dark reddish brown, becoming lighter posteriorly. The paramedian stripe is usually a lighter color should than median stripe, but has a darker outer margin that is similar in coloration to the median stripe. Each tip of the paramedian stripe has either a separate or attached, widely separated reddish-brown stripe that often has an irregular shaped edge (the acrostichal bristles are generally on the outer edge of each stripe). On $P$. gracilis, these stripes are widely separated posteriorly and may be called the postsutural acrostichal stripes. Cannings (2002) called the paired "...stripes on the scutum to be the acrostichal stripe..."

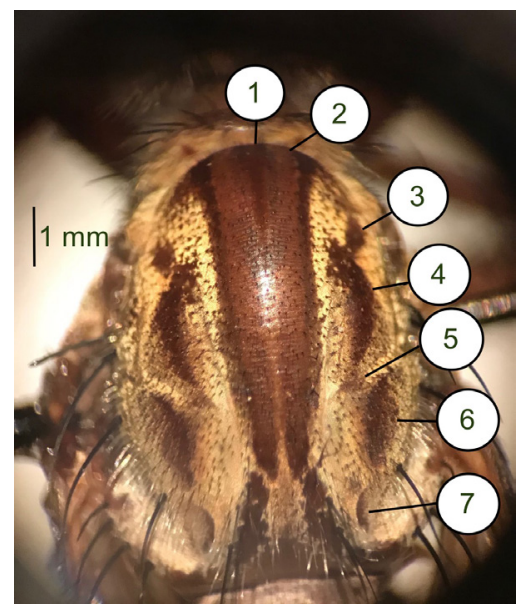

Fig. 2. Dorsal view of Proctacanthus gracilis thorax showing stripes and spots (Photograph: J.G. Dennis, 06.01.2020, 10:49 AM). Number designations: 1, Median stripe of scutum; 2, Paramedian stripe of scutum; 3, Posthumeral spot; 4, Presutural spot; 5, Sutural spot; 6, Postsutural spot; and 7, Prescutellar spot and postsutural acrostichal stripe.

The dorsal thoracic spots on $P$. gracilis are reddish brown and may be very dark. The posthumeral spot is often broadly "U" shaped (in particular on the asilids in the 


\section{Ethology of Proctacanthus gracilis}

MCCA), merged with the presutural spot and extend laterally to the outer margin of the paramedian stripe. The presutural spot may be triangular or elongate and have an outer lighter margin. If elongate, the presutural spot is usually slightly concave towards the paramedian stripe. The presutural spot also may be only slightly separated from or partially merged with the postsutural spot. The sutural spot is very small, indistinct, or absent. If present, the sutural spot is close to the paramedian stripe, light reddish brown, circular to more elongate or triangular. The postsutural spot is usually somewhat shaped like a triangle with a lighter margin, although it may consist of a convex curved stripe with a lighter margin. The prescutellar spot is indistinct to dark reddish brown and shaped like a small triangle or crescent. Sometimes, on either side of the paramedian stripe, there is a light reddish-brown to light blackish area that blends into the spots and makes them difficult to see.

In addition to the pale setae on the coxae of the legs of $P$. gracilis mentioned by Bromley (1928), the coxae may have one to six (usually 1 or 2) medial black bristles, one of which is usually longer and larger than the others. Some specimens may have one to four medial pale bristles instead of the black bristles or the pale bristles are below the black bristles.

Bromley (1928) described, $P$. gracilis with "... an obscure brownish area in the center of each segment forming a broken median line along the dorsum of the abdomen." This median line is faint brownish to dark reddish brown.

In Hine's (1911) key to the species of Proctacanthus, $P$. gracilis would key to the last couplet 15 with the smaller $P$. brevipennis (Wiedemann, 1828). The two species can be distinguished from each other as follows, (1) $P$. gracilis has palpi with all or almost all white hairs (bristles) and $P$. brevipennis palpi have black hairs; (2) P. gracilis has reddish femora and $P$. brevipennis has black femora or a black anterior stripe (in particular on the fore femora); and (3) $P$. gracilis thoracic stripes and spots are reddish brown and $P$. brevipennis stripes are black and the spots are light gray to dark black.

Hine (1911) indicates that $P$. brevipennis has the "...mesothoracic dorsum with the usual markings very plainly differentiated..." Like $P$. gracilis, the stripes narrow from anterior to posterior, but the median stripe is dark black, the paramedian stripe is lighter black with a darker margin, and the postsutural acrostichal stripe is reddish brown to black and connected to or blends into each side of the paramedian stripe. Anteriorly on either side of the stripes, the thorax is light reddish to reddish-orange/ brown and extends to at least half of the postpronotal lobe. The mesothoracic spiracle is reddish brown to brown and the anepisternum is partially to completely black. The posthumeral spot is cup shaped with the "hollow" facing the paramedian stripe, reddish brown to black, and connected to the lighter margin of the presutural spot. The latter has a dark black, elongate area surrounded by a light to dark gray margin. The sutural spot, if present, is light gray and oval; it often blends into the presutural and postsutural spots. The postsutural spot is light gray to brownish and may have a darker convex, crescent-shaped area. The prescutellar spot is generally triangular, dark brown to black with a posterior shiny grayish area that extends onto the postalar callus. 


\section{Habitat and distribution in Florida}

In the MCCA, as part of vegetation management, the St. Johns River Water Management District mows and roller drum chops scrub, scrubby flatwoods, and sandhill communities. Roads are usually mowed every year in the fall and other areas are mowed or rolled drum chopped every few years, depending on the height of vegetation.

Proctacanthus gracilis occurs in the mowed scrub communities and in mowed roads (Fig. 3) that pass through these communities with the vegetation shown in Table 1. In both of these habitats, $15 \mathrm{~cm}$ to $1 \mathrm{~m}$ tall grasses (Poaceae), sedges and nutrushes (Cyperaceae), and rushes (Juncaceae) are dominant. In the mowed scrub communities these plants are generally in areas that vary in size from approximately 30-276 $\mathrm{m}^{2}$ and are surrounded by other plants, in particular fetterbush (Ericaceae, Lyonia lucida (Lam.) K. Koch], scrub oaks (Fagaceae, Quercus spp.), and some saw palmetto [Arecaceae, Serenoa repens (W. Bartram) Small).

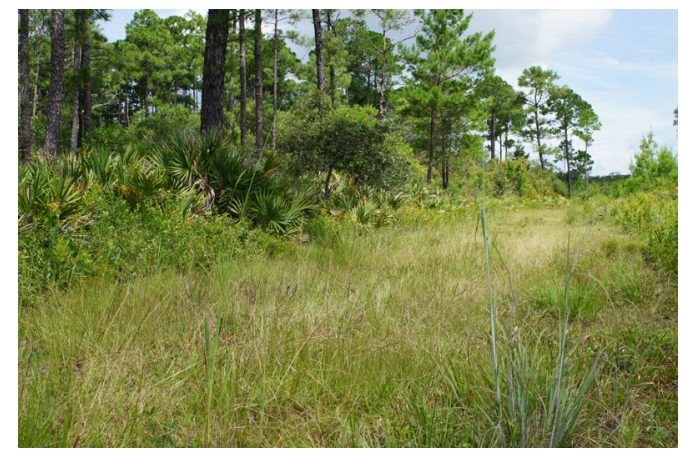

Fig. 3. Proctacanthus gracilis habitat in road in mowed scrub vegetation community (Photograph: D.S. Dennis, 08.08.2013, 11:10 AM).

Proctacanthus brevipennis (Dennis, 2012), P. fulviventris Macquart, 1850 (Dennis, 2015), and P. longus (Wiedemann, 1821) (Dennis, 2019) also occur in the MCCA in mowed and roller drum chopped scrub communities. Bromley (1928) said that Proctacanthus "....inhabit dry fields or pastures, several being restricted to dry sandy plains." Hull (1962) commented that Proctacanthus are found in "...rank grassland and shrubs on the edges of woodlands in swampy country and some prefer sandy river banks."

Material examined: Bromley (1950) reported P. gracilis occurring in Florida in Hillsborough (County), Live Oak (Suwanee County), Sanford (Seminole County), and Wakullah (County). The FSCA has specimens of $P$. gracilis collected from the following locations in Florida with the indicated date of collection, collector, and sex of the robber fly, if known: ALACHUA COUNTY: 21.06.1954 (H.A. Denmark; $1 \delta$ taken in dense woods), 24.06.1954 (H.V. Weems, Jr.; 1 f), 13.05.1955 (H.V. Weems, Jr.; 3 ổ),

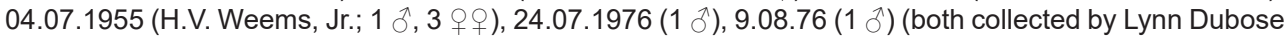
in $\mathrm{CO}_{2}$ Bated South, Insect Flight Trap); Junction SR 225 \& SR 340, 31.08.1976 (Lynn Dubose; 1 q); Gainesville, ?.08.1955 (J.D. Morrison, Jr.; 1 đ)), 08.10.1955 (F.L. Wilson; 1 +), 24.08.1957 (H.V. Weems, Jr.; 1 §), 25.06.1958 (H.V. Weems, Jr.: 1 \& In Wooded Ravine), 05.08.1962 (R.E. Woodruff; 1 §); 5.6 km NE Gainesville, Airport Area, 16.06.1991 (Lloyd R. Davis, Jr.; 4 ô, 8 qo; 1 ô with Orthoptera,

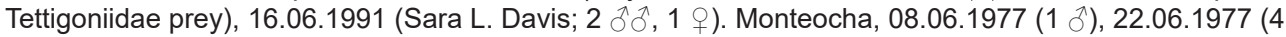




\section{Ethology of Proctacanthus gracilis}

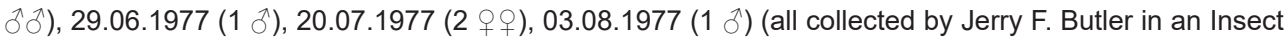
Flight Trap). BREVARD COUNTY: Melbourne, 09.07.1951 (Price, Beamers, Wood; sex unknown since abdomen missing). DUVAL COUNTY: Jacksonville, 21.06.1958 (Ribble; 1 \&), 22.06.1963 (F.J. Santana; 1 †); NAS Cecil Field, Jacksonville, 08.08.1963 (F.J. Santana; 1 đ). HILLSBOROUGH COUNTY: U.S.F. Campus, 25.05.1985 (1 +), 30.05.1985 (1 đ), 13.06.1985 (1 §) (all collectors unknown). LEVI COUNTY: 30.06 .56 (H.V. Weems, Jr.; 1 O, 1 क)); Rosewood, 19.08.1991 (Lloyd R. Davis, Jr.; 1 ô, 3 우우). LIBERTY COUNTY: Torreya State Park, 04.07 .1965 (H.V. Weems, Jr.; 1 ठ̋). OKALOOSA COUNTY: Choctawhatchee Bay, Niceville, 12.08.1959 (Bill Platt; 1 o Caught on Screen). PUTNAM COUNTY:

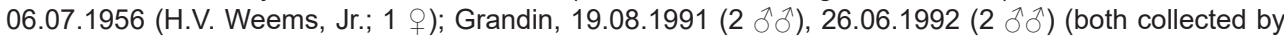
Lloyd R. Davis, Jr.); 5.6 km NE of Grandin, 30.08.1991 (Lloyd R. Davis. Jr.;1 \&). SANTA ROSA COUNTY: 02.08.1955 (F.W. Mead; 1 \&). ST. JOHNS COUNTY: 03.09.1955 (H.V. Weems, Jr.; 2 ð̋).

Table 1. Vegetation in communities in which Proctacanthus gracilis was studied in the Moses Creek Conservation Area.

\begin{tabular}{|c|c|c|}
\hline Vegetation Type & \multicolumn{2}{|c|}{ Vegetation Community } \\
\hline Family/Genus/Species/Common Name & $\begin{array}{l}\text { Mowed Scrub } \\
\text { Community }\end{array}$ & $\begin{array}{l}\text { Mowed Vegetation } \\
\text { in Roads in Mowed } \\
\text { Scrub Community }\end{array}$ \\
\hline \multicolumn{3}{|l|}{ Aquifoliaceae } \\
\hline Ilex opaca Alton var. opaca/American holly & $x$ & - \\
\hline \multicolumn{3}{|l|}{ Arecaceae } \\
\hline Serenoa repens (W. Bartram) Small/saw palmetto & $x$ & - \\
\hline \multicolumn{3}{|l|}{ Asteraceae } \\
\hline $\begin{array}{l}\text { Carphephorus corymbosus (Nutt.) Torr. \& A. Gray/ coastalplain chaffhead (Florida } \\
\text { paintbrush) }\end{array}$ & $x$ & - \\
\hline Eupatorium sp./fennel (thoroughwort) & $\mathrm{x}$ & $\mathrm{x}$ \\
\hline Erechtites hieraciifolius (L.) Raf. ex DC./American burnweed (fireweed) & $x$ & - \\
\hline Liatris tenuifolia Nutt./ shortleaf gayfeather & $x$ & $x$ \\
\hline Pityopsis graminifolia (Michx.) Nutt./narrowleaf silkgrass & $x$ & - \\
\hline \multicolumn{3}{|l|}{ Cyperaceae } \\
\hline Carex sp./sedge & - & $x$ \\
\hline Cyperus spp./flatsedge & $x$ & $x$ \\
\hline Rhynchospora colorata (L.) H. Pfeiff./starrush whitetop & - & $x$ \\
\hline Rhynchospora spp./beaksedge & $x$ & - \\
\hline Scleria sp./nutrush & $\mathrm{x}$ & $\mathrm{x}$ \\
\hline \multicolumn{3}{|l|}{ Dennstaedtiaceae } \\
\hline $\begin{array}{l}\text { Pteridium aquilinum L. (Kuhn) var. pseudocaudatum (Clute) Clute ex A. Heller/tailed } \\
\text { bracken }\end{array}$ & $x$ & - \\
\hline \multicolumn{3}{|l|}{ Ericaceae } \\
\hline Ceratiola ericoides Michx./Florida rosemary (sand heath) & $x$ & - \\
\hline Lyonia lucida (Lam.) K. Koch/ fetterbush & $x$ & - \\
\hline \multicolumn{3}{|l|}{ Eriocaulaceae } \\
\hline Lachnocaulon sp./bogbutton & $x$ & - \\
\hline
\end{tabular}


Table 1. Continued.

\begin{tabular}{|c|c|c|}
\hline Vegetation Type & \multicolumn{2}{|c|}{ Vegetation Community } \\
\hline Family/Genus/Species/Common Name & $\begin{array}{l}\text { Mowed Scrub } \\
\text { Community }\end{array}$ & $\begin{array}{l}\text { Mowed Vegetation } \\
\text { in Roads in Mowed } \\
\text { Scrub Community }\end{array}$ \\
\hline \multicolumn{3}{|l|}{ Fabaceae } \\
\hline Galactia elliottii Nutt./Elliott's (white) milkpea & $\mathrm{x}$ & $x$ \\
\hline \multicolumn{3}{|l|}{ Fagaceae } \\
\hline Quercus spp./scrub oaks & $x$ & - \\
\hline \multicolumn{3}{|l|}{ Haemodoraceae } \\
\hline Lachnanthes caroliana (Lam.) Dandy/Carolina redroot & $\mathrm{x}$ & $x$ \\
\hline \multicolumn{3}{|l|}{ Hypoxidaceae } \\
\hline Hypoxis juncea Sm./fringed yellow stargrass & - & $x$ \\
\hline \multicolumn{3}{|l|}{ Juncaceae } \\
\hline Juncus sp./rush & $x$ & - \\
\hline \multicolumn{3}{|l|}{ Pinaceae } \\
\hline Pinus clausa (Chapm. ex Engelm.) Vasey ex Sarg./sand pine & $\mathrm{x}$ & $\mathrm{x}$ \\
\hline Pinus elliottii Engelm./slash pine & $\mathrm{x}$ & - \\
\hline \multicolumn{3}{|l|}{ Poaceae } \\
\hline $\begin{array}{l}\text { Andropogon glomeratus (Walter) Britton et al. var. glaucopsis (Elliott) C. Mohr/purple } \\
\text { bluestem }\end{array}$ & $x$ & $\mathrm{x}$ \\
\hline Andropogon virginicus L. var. glaucus Hack./chalky bluestem & - & $x$ \\
\hline Aristida spiciformes Elliott / bottlebrush threeawn & $\mathrm{x}$ & - \\
\hline Aristida stricta Michx./wiregrass & $x$ & - \\
\hline Sorghastrum secundum (Elliott) Nash/lopsided Indiangrass & $\mathrm{x}$ & - \\
\hline Axonopus sp./carpetgrass & - & $x$ \\
\hline \multicolumn{3}{|l|}{ Polygalaceae } \\
\hline Polygala lutea L./orange milkwort & $\mathrm{x}$ & $\mathrm{x}$ \\
\hline \multicolumn{3}{|l|}{ Saururaceae } \\
\hline Saururus cernuus L./lizard's tail & $\mathrm{x}$ & $\mathrm{x}$ \\
\hline \multicolumn{3}{|l|}{ Smilacaceae } \\
\hline Smilax auriculata Walter/earleaf greenbrier vine & $x$ & - \\
\hline Smilax bona-nox L./saw greenbrier vine & $\mathrm{x}$ & - \\
\hline \multicolumn{3}{|l|}{ Xyridaceae } \\
\hline Xyris sp./yelloweyed grass & $x$ & $\mathrm{x}$ \\
\hline
\end{tabular}

$\mathrm{X}=$ present; - = not present. 


\section{Ethology of Proctacanthus gracilis}

\section{Resting behavior}

Proctacanthus gracilis only rest on live vegetation, typically $5 \mathrm{~cm}-1 \mathrm{~m}$ above the ground with an average of $35 \mathrm{~cm}(n=20)$. They usually rest with their bodies parallel to the vegetation (e.g., grass stem) and vertical to the ground. Although sometimes they will straighten their hind legs and have their bodies at a $45^{\circ}$ angle so that it looks like they are leaning forward. If they rest in a more horizontal position they may extend their fore legs so that their bodies are at a $45^{\circ}$ angle with the abdomen almost touching the vegetation that they rest on. They usually remain in these positions for 19.0-33.5 minutes (average 24.4 minutes, $n=5$ ). Although one female remained vertical to the ground holding onto a dead sedge stalk for 1 hour and 43.5 minutes, with only four slight adjustments in her position and one short $(20 \mathrm{~cm})$ flight to another stalk during this period of time.

When resting, in particular in shade of surrounding vegetation, $P$. gracilis will usually remain stationary. A few move their heads in response to other insects flying by and one male groomed (four times) his fore tarsi and head with his fore tibiae and proximal part of the fore tarsi.

When $P$. gracilis are resting in shade they will often flatten themselves against the substrate that they are on. As their bodies become exposed to the sun, they will make other postural adjustments, including facing the sun or elevating one side of their bodies to the sun. These postural adjustments have been shown to maintain the body temperature of many other species of robber flies (Dennis \& Lavigne, 1975; Morgan, Shelly, \& Kimsey, 1985; Morgan \& Shelly, 1988), including P. brevipennis (Dennis, 2012), P. fulviventris (Dennis, 2015), and P. longus (Dennis, 2019) in the MCCA.

If it starts to rain when $P$. gracilis is resting on vegetation stalks, they will hold their bodies closer to the stalk.

While resting and feeding, $P$. gracilis often expel drops of creamy white or white drops of liquid from their anus. Generally more (three to four) or larger drops are expelled during feeding than when resting.

Abdominal pumping of the first two abdominal segments was observed in one female while resting. Pumping of the first three abdominal segments was observed in one male during feeding. In the laboratory, Morgan and Shelly (1988) observed Promachus giganteus Hine, 1911 pumping haemolymph into the abdomen to regulate thoracic temperatures. Proctacanthus gracilis may exhibit similar behavior in the field to regulate its body temperature. Musso (1968) and Lavigne \& Holland (1969) attributed abdominal pumping or contractions during feeding to the injection of proteolytic enzymes into prey and food pumping.

\section{Foraging and feeding behavior}

Proctacanthus gracilis almost always forage from the tops and sides of live and dead vegetation. Only one female foraged from the ground. When foraging, their bodies are either horizontal or parallel to the vegetation or they are at a $30-45^{\circ}$ angle with the fore legs extended. The latter position is particularly common when the asilids face the sun, which presumably allows them to better see potential prey because of 
backlighting. Proctacanthus brevipennis (Dennis, 2012), P. fulviventris (Dennis, 2015), P. longus (Dennis, 2019), P. nearno (Lavigne \& Dennis, 1979), and P. micans (Dennis \& Lavigne, 1975) have similar foraging positions.

Proctacanthus gracils make three types of foraging flights: flights that are not directed at potential prey (i.e., orientation flights); flights directed at potential prey without coming into contact with them (i.e., investigatory flights); and flights when they capture and release potential prey or capture prey. After making these flights $P$. gracilis would sometimes re-land at their original foraging position or within $5-15 \mathrm{~cm}$ of their original position $(n=8)$, but most of the time they would re-land $20.0 \mathrm{~cm}-6.1 \mathrm{~m}$ (average $1.2 \mathrm{~m} ; \mathrm{n}=35$ ) from their original position.

Proctacanthus gracilis will often remain in the same location for 2-11 minutes (average 6.6 minutes; $n=6$ ) between making orientation flights and moving to new locations. Flights to new locations are direct and do not involve weaving in and out of vegetation.

Investigatory flights are for distances of $5.0-60.0 \mathrm{~cm}$ (average $11.4 \mathrm{~cm} ; \mathrm{n}=18$ ) to the side of or in front of a foraging position, and $10.0-50.0 \mathrm{~cm}$ (average $27.8 \mathrm{~cm} ; \mathrm{n}=17$ ) above the ground. Both male and female $P$. gracilis would often follow grasshoppers until they landed on vegetation or on the ground and then the robber fly would stop pursuing the potential prey. This indicates that visual stimuli, including prey movement, are required to elicit predatory response from $P$. gracilis. Lavigne \& Holland (1969) found that the robber flies they studied reacted to lure motion and size.

Foraging flights when $P$. gracilis capture and release prey are also made to the side of or in front of their foraging positions. These flights are made for distances of 5.0-61.0 $\mathrm{cm}$ (average $32.8 \mathrm{~cm} ; \mathrm{n}=4$ ) and 15.0-30.0 $\mathrm{cm}$ (average 23.8; $\mathrm{n}=4$ ) above the ground.

Proctacanthus gracilis captures all of its prey in the air when the prey are within $30.0-150 \mathrm{~cm}$ (average $65.8 \mathrm{~cm} ; \mathrm{n}=8$ ) behind, in front of, or to the side of their foraging location and 7.5-91.4 cm (average $33.4 \mathrm{~cm} ; \mathrm{n}=8$ ) above the ground. Proctacanthus brevipennis (Dennis, 2012), P. fulviventris (Dennis, 2015), and P. longus (Dennis, 2019) captured all of their prey in flight; whereas, $P$. micans (Dennis and Lavigne, 1975), and $P$. nearno (Lavigne and Dennis, 1979) captured most of their prey in flight. Proctacanthus micans also captured prey on vegetation and $P$. nearno captured some prey as they were landing on the ground.

When capturing large prey, such as adult grasshoppers, $P$. gracilis would either immediately insert its proboscis and then fall into vegetation holding onto prey with all six tarsi or fall into vegetation and insert its proboscis while holding onto prey with the tarsi. The asilids would hold onto the captured prey for up to seven minutes before standing up on the vegetation. One male asilid fell into vegetation holding onto the grasshopper prey with all six tarsi and then released the grasshopper without inserting its proboscis.

After capturing small prey, such as grasshopper nymphs or some Diptera, $P$. gracilis would hover, hold onto the prey with all six tarsi, insert its proboscis, and then land on vegetation. They insert the proboscis most frequently in the side or back of the prey's head. They inserted the proboscis into the side or dorsal surface of the thorax in a few prey captures. In one adult grasshopper the proboscis was inserted in the 


\section{Ethology of Proctacanthus gracilis}

side of the neck; and in another adult grasshopper the proboscis was inserted in the side of the abdomen just posterior of the hind leg.

Male and female $P$. gracilis captured prey that are approximately the same length. Average prey length for males is $16.6 \mathrm{~mm}(\mathrm{n}=19)$ with a range of $10.5-35.0 \mathrm{~mm}$. For females the average prey length is $16.2 \mathrm{~mm}(\mathrm{n}=27)$ with a range of $9.0-33.0 \mathrm{~mm}$. The overall mean prey length is $16.4 \mathrm{~mm}$ with a predator to prey ratio of 1.7:1.0 which indicates that $P$. gracilis is between 1.5 to 2 times larger than its prey. Mean predator to prey ratios for $P$. brevipennis (Dennis, 2012), P. fulviventris (Dennis, 2015), P. longus (Dennis, 2019), and P. micans (Dennis and Lavigne, 1975), are 3.0:1.0, 1.9:1.0, 1.7:1.0, and 2.0:1.0, respectively. Mean predator to prey ratios for other species of robber flies range from 0.9:1.0 to 8.4:1.0 (Dennis, 2016), with a mean of 2.8:1.0.

Proctacanthus gracilis moves to a new location up to eight times while feeding on prey. When it moves, it is to a location that averages $95.2 \mathrm{~cm}$ (range $2.5 \mathrm{~cm}$ to 4.6 $\mathrm{m} ; \mathrm{n}=23$ ) from the previous location.

During feeding, $P$. gracilis either does not manipulate small prey (e.g., grasshopper nymphs and Diptera) or it manipulates them up to two times with all six tarsi in a hover above the feeding site. It also manipulates large prey (e.g., adult grasshoppers) up to two times while holding the prey against vegetation and crawling on or moving the prey with a combination of tarsi, before reinserting its proboscis.

When $P$. gracilis is feeding, prey less than $13.5 \mathrm{~mm}$ long (e.g., Apis mellifera L., 1878) generally hang free from the asilid's proboscis without support by the tarsi or vegetation. Prey around $18.8 \mathrm{~mm}$ long [smaller Orphulella pelidna (Burmeister, 1838); Acrididae] would hang free or be supported by a combination of tarsi. For longer prey greater than approximately $24.5 \mathrm{~mm}$ [e.g., Spharagemon marmorata (Harris, 1841); Acrididae], an asilid would use its body to hold prey against vegetation while grasping the vegetation with its tarsi or would hold vegetation with a combination of tarsi and support the prey with the rest of its tarsi.

Nine complete $P$. gracilis feedings were observed and ranged from 17-355 minutes ( 5 hours and 55 minutes) with an average of 167 minutes ( 2 hours and 47 minutes). The time spent feeding correlates with prey length. One asilid fed on an unidentified grasshopper nymph, with a length of $13 \mathrm{~mm}$, for 49 minutes; whereas, $P$. gracilis fed on adult grasshoppers with lengths ranging from $20.5-33.0 \mathrm{~mm}$, for $105-355$ minutes (average about 258 minutes; $n=5$ ). For a number of other species of robber flies, the time spent feeding usually depends on prey length (Dennis, 2019).

At the completion of feeding, $P$. gracilis discards prey in one of three ways: (1) it pushes prey off its proboscis with the fore tarsi while still at the feeding site $(n=1)$; (2) it allows prey to drop off its proboscis at the feeding site $(n=4)$; or $(3)$ it drops prey in flight as it moves to a new location $(n=6)$. The latter is the most common way of discarding prey. Other species of Proctacanthus use similar methods to discard prey (Dennis, 2019). In addition, P. fulviventris (Dennis, 2015), P. longus (Dennis, 2019), and $P$. micans (Dennis \& Lavigne, 1975) drop prey while hovering at the feeding site; and $P$. micans pushes prey off its proboscis with the fore tarsi during its flight to a new location. 
Because of the length of feedings and flight speeds flown to new locations after feeding, inter-feeding times (time between feedings) were difficult to obtain. Thus, only one inter-feeding time of 66.5 minutes, was obtained.

The theoretical number of prey an individual $P$. gracilis can feed on in one day can be calculated if one assumes that: (1) it continually forages and feeds between 9:00 AM and 3:00 PM (the time when individuals were found with prey), and (2) it captures and feeds on prey every 233.5 minutes (the average feeding time and one inter-feeding time). Therefore, over a 6-hour period (360 minutes) an individual can feed on approximately 1 to 2 prey. Species of Proctacanthus that generally feed on smaller prey and/or have shorter feeding and inter-feeding times can feed on an estimated 3 to 8 prey per day (Dennis, 2012, 2015, 2019; Dennis \& Lavigne, 1975). Dennis (2016) reported that other investigators estimate robber flies feed on 1 to 35 prey per day.

\section{Prey}

Proctacanthus gracilis feed on Coleoptera, Diptera, Hemiptera, Hymenoptera, Lepidoptera, Neuroptera, Odonata, and Orthoptera (Table 2). However, the majority of prey is Orthoptera $(63.0 \%$ ) with each of the other orders making up $2.2-8.5 \%$ of the prey. Bromley (1950) reported $P$. gracilis preying on honeybees (Apis mellifera) in a bee yard in Live Oak, Florida, during August. Fattig (1945) also reported $P$. gracilis feeding on honeybees in Georgia in August and on the robber fly Megaphorus clausicellus (Macquart, 1850) (as Mallophora clausicella).

Dennis (2012) reported P. brevipennis feeding on six insect orders (Coleoptera, Diptera, Hymenoptera, Isoptera, Lepidoptera, and Orthoptera) with most prey Coleoptera $(59.7 \%)$ and Hymenoptera (17.7\%). Proctacanthus fulviventris (Dennis, 2015) fed on only Diptera (12.0\%) and Hymenoptera (88.0\%), and P. Iongus (Dennis, 2019) fed on Coleoptera, Diptera, Hemiptera, Hymenoptera, Lepidoptera, Neuroptera, and Orthoptera with most prey Diptera (43.3\%) and Orthoptera (24.3\%).

The following is a list of prey taken by $P$. gracilis with the number and sex of the predator following the prey record.

COLEOPTERA, Cicindelidae: Cicindela hirtipes LeConte, 1875, 11.06.2013 (1 +)), 12.06.2013 (1 đ̂). Elateridae: Blauta cribraria (Germar, 1843), 17.06.2014 (1 +). DIPTERA, Asilidae: Efferia tabescens 12.07.2017 (1 j); Proctacanthus gracilis Bromley, 1928, 05.08.2014 (1 §). Tabanidae: Tabanus sp. poss. gracilis Wiedemann, 1828, 12.06.2014 (1 q). Unidentified Family: 23.05.2016 (1 §̂). HEMIPTERA, Homoptera, Cicadidae: Cicadetta calliope floridensis (Davis, 1920), 08.08.2011 (1 ㅇ), 17.06.2013 (1 +). HYMENOPTERA, Apidae: Apis mellifera L., 1878, 03.06.2016 (1

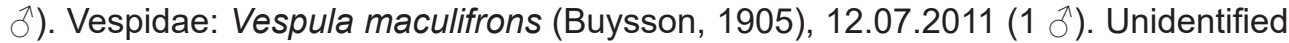
Family: 12.06.2014 (1 + ). LEPIDOPTERA, Unidentified: moth, 23.05.2016 (1 $)^{\text {) }}$. NEUROPTERA, Myrmeleontidae: Myrmeleon carolinus Banks, 1943, 29.07.2011 (1 §). ODONATA, Libellulidae: Erythrodiplax minuscula Rambur, 1842, 24.07 .15 (1 + ). ORTHOPTERA, Acrididae: Achurum carinatum (Walker, 1870), 05.08.2014 (1 3 ); Amblytropidia mysteca (Saussure, 1861), 03.06.16 (1 P); Chortophaga australior Rehn and Hebard, 1911, 01.06.2016 (1 †); Orphulella pelidna (Burmeister, 1838), 
Ethology of Proctacanthus gracilis

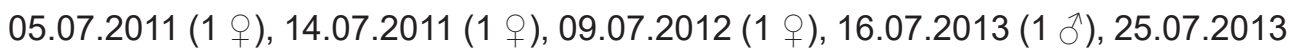

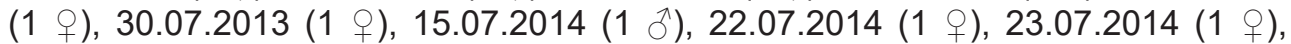

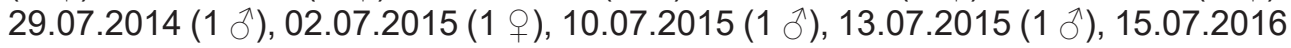
(1 ㅇ), 20.07.2017 (1 §̂); Spharagemon cristatum Scudder, 1875, 02.06.2011 (1 P); Spharagemon marmorata (Harris, 1841), 09.07.2015 (1 §); unidentified, 03.06.11

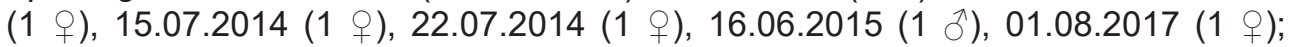

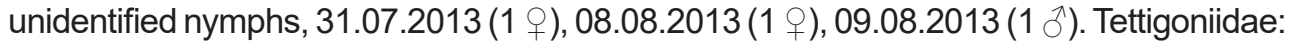
unidentified, 01.08.2014 (1 + ). UNIDENTIFIED Order: 05.07.11 (1 ㅇ), 17.06.13 (1 ఓ).

Table 2. Number and percent composition of orders of prey taken by Proctacanthus gracilis.

\begin{tabular}{|l|c|c|c|c|c|c|}
\hline & \multicolumn{2}{|c|}{ Male } & \multicolumn{2}{c|}{ Female } & \multicolumn{2}{c|}{ Total } \\
\hline \multicolumn{1}{|c|}{ Order } & Number & Percent & Number & Percent & Number & Percent \\
\hline Coleoptera & 1 & 5.3 & 2 & 7.4 & 3 & 6.5 \\
\hline Diptera & 3 & 15.7 & 1 & 3.7 & 4 & 8.8 \\
\hline Hemiptera & 0 & 0 & 2 & 7.4 & 2 & 4.3 \\
\hline Hymenoptera & 2 & 10.5 & 1 & 3.7 & 3 & 6.5 \\
\hline Lepidoptera & 1 & 5.3 & 0 & 0 & 1 & 2.2 \\
\hline Neuroptera & 1 & 5.3 & 0 & 0 & 1 & 2.2 \\
\hline Odonata & 0 & 0 & 1 & 3.7 & 1 & 2.2 \\
\hline Orthoptera & 10 & 52.6 & 19 & 70.4 & 29 & 63.0 \\
\hline Unidentified & 1 & 5.3 & 1 & 3.7 & 2 & 4.3 \\
\hline \multicolumn{1}{|c|}{ Totals } & $\mathbf{1 9}$ & $\mathbf{1 0 0 . 0}$ & $\mathbf{2 7}$ & $\mathbf{1 0 0 . 0}$ & $\mathbf{4 6}$ & 100.0 \\
\hline
\end{tabular}

Male and female $P$. gracilis generally feed on the same insect orders, although more prey insects are usually collected for females than for males. Many investigators have reported collecting more female robber flies with prey than males with prey (Dennis, 2016).

\section{Mating behavior}

Male $P$. gracilis perform searching flights for receptive females with which to mate. Searching flights consist of males flying in an erratic pattern or weaving in and out of vegetation. Sometimes, depending on the distance flown, there would be four to five slight vertical undulations. When actively searching, males would make a flight every 10-75 seconds (average approximately 38 seconds; $n=18$ ) for distances of $1.5-10.1 \mathrm{~m}$ (average $4.2 \mathrm{~m} ; \mathrm{n}=29$ ), at $10.0-30.0 \mathrm{~cm}$ (average $15.3 \mathrm{~cm} ; \mathrm{n}=23$ ) above the ground. Male searching flights have been described for $P$. brevipennis (Dennis, 2012), P. fulviventris (Dennis, 2015), P. longus (Dennis, 2019), and P. micans (Dennis and Lavigne, 1975).

Proctacanthus gracilis usually initiates matings in-flight when a male lands on the dorsum of a female's thorax and clasps the female's genitalia from below. Then the pair fall to the ground or into vegetation where they straighten out in the tail-to-tail position. One male landed on the dorsum of a female shortly after she landed on vegetation and clasped her genitalia. Then the pair straightened out in the tail-to-tail position. Some males had trouble clasping females in flight and were not successful 
until after the pair fell to the ground or into vegetation. Even then the males would often take a few seconds to clasp the female's genitalia. One male unsuccessfully tried to clasp a female's genitalia for 205 seconds before the female flew off.

After mating begins, the pair sometimes flies to a vertical position on a grass stem in the shade of surrounding vegetation, approximately $30-60 \mathrm{~cm}$ above the ground. Either both sexes hold onto the stem or one holds onto the stem with its head up and the other hangs free with its head down.

When one mating pair had been in the tail-to-tail position for 39 minutes, another male landed on the female (Fig. 4). He then proceeded to try and mate with the female and in the process clasped and unclasped both the mating male's and female's genitalia. After 27.5 minutes, the second male flew off.

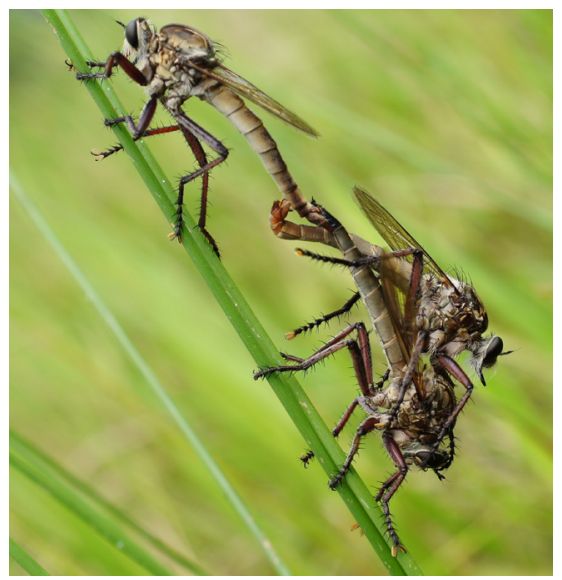

Fig. 4. Mating pair of Proctacanthus gracilis in tail-to-tail position with another male attempting to mate with the female (Photograph: D.S. Dennis, 08.08.2013, 10:59 AM).

The asilids' wings are generally closed during mating. One male had his left wing slightly open during mating. Another male opened and closed his wings slightly after approximately 112 minutes of mating, and after 118 minutes of mating opened and closed his wings to $a 5^{\circ}$ angle and then a $30^{\circ}$ angle. The female of this same mating pair held onto a grass stem below the male and after both 93.5 and 114 minutes of mating released the grass stem, swung up and grasped the male so that the she briefly faced the male and then resumed her position holding onto the grass stem below the male. The female unsuccessfully tried to grab the male again after 125 and 135.5 minutes of mating, after which the male released the female and both asilids flew off.

During mating, $P$. gracilis usually move very little, except when exposed to the sun. Then they relocate to a position in the shade where it is slightly cooler. Mating occurs when the air temperature at the height of mating in the sun range from $30.0-36.0^{\circ} \mathrm{C}$ (average $33.7^{\circ} \mathrm{C} ; \mathrm{n}=10$ ) and in the shade range from $30.5-34.0^{\circ} \mathrm{C}$ (average $32.8^{\circ} \mathrm{C} ; \mathrm{n}=7$ ).

At the completion of mating, male $P$. gracilis unclasp the female's genitalia and both asilids fly off or the pair fly into the air in the tail-to-tail position and then separate. 


\section{Ethology of Proctacanthus gracilis}

The author observed four complete matings of $P$. gracilis that lasted 66.0 to 135.5 minutes with an average of 94.0 minutes. Proctacanthus brevipennis mated for 78.0 to 111.0 minutes with an average of 90.0 minutes (Dennis, 2012); P. fulviventris mated for 30.0 to 63.5 minutes with an average of 40.6 minutes (Dennis, 2015); $P$. longus mated for 106.0 to 116.0 minutes with an average of 111.0 minutes (Dennis, 2019); and P. micans mated for 23.0 to 66.0 minutes with an average of 42.0 minutes (Dennis and Lavigne, 1975).

\section{Oviposition behavior}

One oviposition was observed at 11:03 AM (19.07.2011) in a road that consisted of compacted sugar sand (fine silt made up of ultrafine mineral sand mixed with a large percentage of organic granules). The female was in the shade of surrounding vegetation and inserted her ovipositor in the sand approximately $6 \mathrm{~mm}$. She had her wings closed over her slightly curved abdomen and oviposited for 53 seconds. Then the female quickly withdrew her ovipositor from the sand and swept the sand with the tip of her ovipositor for 27 seconds, and flew off. Sand was collected and examined for eggs, but none were found.

The air temperature above the oviposition site was $30.0^{\circ} \mathrm{C}$; the sand surface temperature was $29.5^{\circ} \mathrm{C}$, and just below the surface, the temperature was $29.0^{\circ} \mathrm{C}$.

At a later date (15.08.2014), a female was observed probing the ground with her ovipositor at 11:01 AM when the sky was overcast. The air temperature was $29.5^{\circ} \mathrm{C}$ and the surface temperature of the ground was $32.5^{\circ} \mathrm{C}$.

\section{Grooming behavior}

Proctacanthus gracilis, like Holopogon snowi (Dennis, 2018) and H. phaeonotus (Dennis, 2014), did not frequently groom themselves. This may be because these asilids occupy various heights on vegetation and do not frequently land on or spend much time on the ground. When $P$. gracilis did groom it was in much the same way as reported for other species of Proctacanthus and other robber flies (Dennis, 2019). They always use the fore legs to groom their heads, and the hind legs to groom their wings and abdomen. Grooming of the head follows feeding, and grooming of the abdomen follows mating, although $P$. gracilis also frequently groom while resting and between foraging flights.

Grooming of the head is sometimes preceded by rubbing together of the fore tarsi. When grooming the head, P. gracilis uses the distal part of the fore femora (Fig. 5), the entire tibiae, and the proximal part of the tarsi, or only the tibiae and/or tarsi. Also, they often turn their head while grooming.

Proctacanthus gracilis sometimes rub the hind tarsi together before curving the abdomen down and grooming $1 / 4$ to $1 / 2$ of the abdomen and $1 / 4$ to $1 / 3$ of the wings. One female pulled her abdomen down to a $90^{\circ}$ angle with her hind legs before grooming her abdomen and wings. Grooming of the wings and abdomen always proceeded from anterior to posterior with the hind tibiae and/or tarsi. When the wings are closed, only the top surface is groomed; when the wings are spread at a $30-45^{\circ}$ angle to the body, both the tops and bottoms of the wings are groomed outward. 


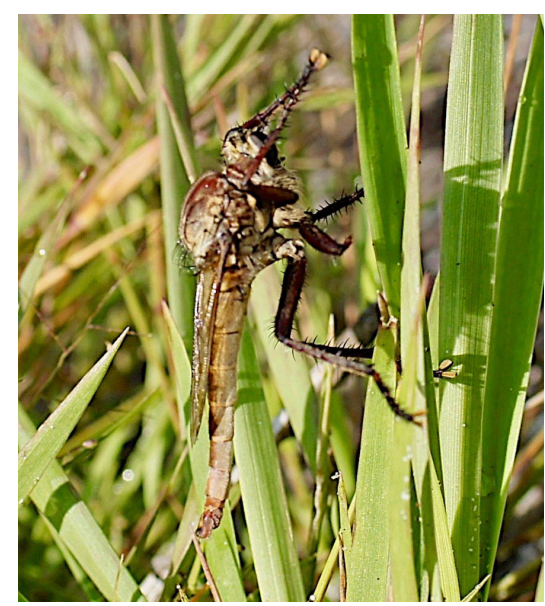

Fig. 5. Male Proctacanthus gracilis grooming head (Photograph: D.S. Dennis, 28.08.2014, 9:01 AM).

\section{Daily rhythm of activity}

Proctacanthus gracilis exhibit a diurnal or daily rhythm of activity between 9:00 AM and 3:00 PM for feeding and mating, with most activity between 9:00 AM and $12: 00$ noon ( $84.8 \%$ of feedings and $92.4 \%$ of matings). As indicated above, only one oviposition was observed at 11:03 AM.

The number of feeding $P$. gracilis peaked in the morning between 10:00-11:00 AM $(37.0 \%)$ and then tapered off until the last feedings were observed between 1:00-3:00 PM (4.4\%). The number of mating $P$. gracilis initially peaked between 9:00-10:00 AM (38.5\%) and continued through the peak feeding period between 10:00-11:00 AM (38.5\%). There was a second small mating peak in the afternoon between 2:00-3:00 PM (7.7\%).

In the MCCA and a nearby storm water drainage basin, the peak $P$. brevipennis period of feeding (10:00-11:00 AM) was before the peaks for mating (1:00-2:00 PM) and ovipositing (2:00-3:00 PM) (Dennis, 2012). For $P$. fulviventris these behaviors in the MCCA had similar patterns and all peaked between 10:00-11:00 AM, with ovipositing having the largest peak (Dennis, 2015). Proctacanthus longus had a peak period of feeding from 10:00-11:00 AM, which was between the peak periods of mating (9:00-10:00 AM) and ovipositing (11:00 AM-12:00 noon) (Dennis, 2019).

Förster, Nitabach, \& Holmes (2011) reported that, "Insects display an impressive variety of daily rhythms, which are most evident in their behaviour. Circadian timekeeping systems that generate these daily rhythms of physiology and behaviour all involve three interacting elements: the timekeeper itself (i.e., the clock), inputs to the clock through which it entrains and otherwise responds to environmental cues such as light and temperature, and outputs from the clock through which it imposes daily rhythms on various physiological and behavioural parameters." Lavigne, Dennis, \& Gowen (2000) indicated that a number of environmental variables (e.g., temperature, wind, cloudy weather) affect the behavior of robber flies, with temperature one of the most important. 
Ethology of Proctacanthus gracilis

Temperature appears to affect the behavior of the different species of Proctacanthus studied in the MCCA. With the lower average spring temperatures (Table 3 ), $P$. brevipennis has peak periods of feeding, mating and ovipositing that occur throughout the day. Whereas, as the average temperature increases during the summer, in particular in the afternoon, $P$. fulviventris, $P$. gracilis, and $P$. longus exhibit the major peak periods of these behaviors in the morning.

Table 3. Months with most behavioral observations, peak periods of behaviors, and air temperatures for

Proctacanthus brevipennis, $P$. fulviventris, $P$. gracilis, and $P$. longus in the MCCA.

\begin{tabular}{|c|c|c|c|c|}
\hline \multirow{2}{*}{ Species } & \multirow{2}{*}{$\begin{array}{c}\text { Months With Most } \\
\text { Behavioral Observations }\end{array}$} & \multirow{2}{*}{ Major Peak Periods of Behaviors } & \multicolumn{2}{|c|}{ Air Temperature $\left({ }^{\circ} \mathrm{C}\right)$} \\
\hline & & & Range & Average $(n)$ \\
\hline P. brevipennis & April through May & 10:00 AM-3:00 PM & $17.5-35.8$ & $30.3(42)$ \\
\hline P. fulviventris & June through August & 10:00-11:00 AM & $27.8-39.0$ & $32.6(104)$ \\
\hline P. gracilis & June through August & $9: 00-11: 00 \mathrm{AM}$ & $28.0-36.0$ & $32.5(21)$ \\
\hline P. longus & June through July & 9:00 AM-12:00 noon & $28.0-37.0$ & $31.8(54)$ \\
\hline
\end{tabular}

Depending on the species, the behaviors include feeding, mating, and ovipositing.

\section{Predators and parasites}

One male $P$. gracilis captured a female in flight and inserted his proboscis between the female's dorsal and left posterolateral side of her thorax. Cannibalism is often reported for robber flies (Lavigne et al, 2000).

A female Promachus bastardii (Macquart, 1838) was found feeding on a male $P$. gracilis.

Campsomeris plumipes (Drury, 1770) (Scoliidae) wasps repeatedly hover around $P$. gracilis while they are on vegetation feeding on prey. This causes the robber flies to move up to $1.5 \mathrm{~m}$ from their previous location to avoid the wasps. One female $P$. gracilis feeding on a grasshopper (Spharagemon cristatum) moved eight times.

There are a number of ants (Formicidae, Formica spp. and Solenopsis invicta Buren, 1972) in the same habitats as $P$. gracilis. Sometimes the ants disturb the asilids while they are feeding, causing the asilids to move to a new location.

Mites are found on the sides of the thorax of $P$. gracilis. According to Lavigne et al (2000), mites are often found on the thoraxes of robber flies.

The six-lined racerunner [Cnemidophorus sexlineatus (Linnaeus, 1766)] is a common lizard in the MCAA. One crawled under a female $P$. gracilis resting on vegetation and this resulted in the female flying to a new location. Although racerunners are known to be insectivorous, none preyed on $P$. gracilis.

\section{CONCLUSIONS}

The stripes and spots on the mesonotum are one morphological characteristic that can be used to separate $P$. gracilis from other species of Proctacanthus in the MCCA. Proctacanthus gracilis rests on live vegetation and forages from both live and dead vegetation. They capture prey in flight, and prey consists of Othoptera (63.0\%), Diptera (8.8\%), Coleoptera and Hymenoptera (each 6.5\%), Hemiptera and 
unidentified (each 4.3\%), and Lepidoptera, Neuroptera and Odonata (each 2.2\%). During feeding, $P$. gracilis crawls on prey and manipulates it with a combination of tarsi or manipulates it while hovering above the feeding site. Males search for receptive females with which to mate, but there is no courtship prior to mating. Mating occurs in the tail-to-tail position. Females oviposit in the ground. Peak period for feeding and mating is from 9:00 to 11:00 AM. Grooming is in much the same manner as other asilids. Proctacanthus gracilis exhibits cannibalism and is preyed upon by Promachus bastardii. Mites are found on the sides of the thorax of $P$. gracilis.

\section{ACKNOWLEDGMENTS}

The author thanks the staff of the St. Johns River Water Management District for the issuance of the Special Use Authorization that allows the study of robber flies in the Moses Creek Conservation Area (MCCA) and for their interest in the resulting research.

With gratitude, the author acknowledges the SEL's Matthew Buffington (Scoliidae), David A. Nickle (Acrididae), and Stuart H. McKamey (Cicadidae) for their insect identifications. The author also would like to thank the SEL's Michele Touchet for handling of the prey and the prompt Identification Reports.

The author expresses appreciation to Jeanne Gowen Dennis for taking the picture (Fig. 2) of a thorax of $P$. gracilis, and thanks Gary Steck and Zell Smith for facilitating access to the robber flies in the FSCA.

Finally, sincere thanks go to the anonymous reviewers for their constructive comments on the manuscript.

\section{REFERENCES}

Bromley, S.W. (1928). Notes on the genus Proctacanthus with the description of two new species (Diptera: Asilidae). Psyche, 35, 12-15.

Bromley, S.W. (1950). Florida Asilidae (Diptera) with description of one new species. Annals of the Entomological Society of America, 43(2), 227-239.

Cannings, R.A. (2002). The systematics of Lasiopogon (Diptera: Asilidae). Royal British Columbia Museum, Victoria. $354 \mathrm{pp}$.

Dennis, D.S. (2012). Ethology of Proctacanthus brevipennis (Wiedemann, 1828) (Diptera: Asilidae) in Northeastern Florida, U.S.A. Journal of the Entomological Research Society, 14(3), 91-109.

Dennis, D. S. (2014). Ethology of Holopogon phaeonotus Loew, 1874 (Diptera: Asilidae) in Northeastern Florida, U.S.A. Journal of the Entomological Research Society, 16(2), 141-158.

Dennis, D.S. (2015). Ethology of Proctacanthus fulviventris Macquart, 1850 (Diptera: Asilidae) in Northeastern Florida, U.S.A. Journal of the Entomological Research Society, 17(1), 01-21.

Dennis, D.S. (2016). Ethology of Promachus bastardii (Macquart, 1838) (Diptera: Asilidae) in Northeastern Florida, U.S.A. Journal of the Entomological Research Society, 18(3), 69-92.

Dennis, D.S. (2018). Ethology of Holopogon snowi Back, 1909 (Diptera: Asilidae) in Northeastern Florida, U.S.A. Journal of the Entomological Research Society, 20(1), 95-112.

Dennis, D.S. (2019). Ethology of Proctacanthus longus (Wiedemann, 1821) (Diptera: Asilidae) in 


\section{Ethology of Proctacanthus gracilis}

Northeastern Florida, U.S.A. Journal of the Entomological Research Society, 21(1), 37-56.

Dennis, D.S. \& Lavigne, R.J. (1975). Comparative behavior of Wyoming robber flies II (Diptera: Asilidae). Agricultural Experiment Station University of Wyoming-Laramie Science Monograph No. 30, 68 pp.

Fattig, P. W. (1945). The Asilidae or robber flies of Georgia. Emory University Museum Bulleting Number Three, $33 \mathrm{pp}$.

Förster, C., Nitabach, M.N., \& Holmes, T.C. (2011). Insect circadian clock outputs. Essays in Biochemistry, 49(1), 87-101.

Geller-Grimm, F. (2020, January 04). Robber flies (Asilidae), database, catalog of species. Retrieved from http://www.geller-grimm.de/catalog/species.htm

Hine, J. S. (1911). Robberflies of the genus Promachus and Proctacanthus. Annals of the Entomological Society of America, 4(2), 153-172.

Hull, F. M. (1962). Robber flies of the world. The genera of the family Asilidae. Smithsonian Institution, $U$. S. National Museum Bulletin, 224(1, 2), $907 \mathrm{pp}$.

Lavigne, R. J. \& Dennis, D. S. (1979). Notes on the ethology of Proctacanthus nearno (Diptera: Asilidae) in Mexico. Proceedings of the Entomological Society of Washington, 81(3), 438-442.

Lavigne, R.J., Dennis, D.S., \& Gowen, J.A. (2000). Asilid literature update 1956-1976 including a brief review of robber fly biology (Diptera: Asilidae). Agricultural Experiment Station University of Wyoming Science Monograph, 36, 93 pp.

Lavigne, R.J. \& Holland, F.R. (1969). Comparative behavior of eleven species of Wyoming robber flies (Diptera: Asilidae). Agricultural Experiment Station University of Wyoming Laramie Science Monograph No. 18, 61 pp.

Morgan, K.R. \& Shelly, T.E. (1988). Body temperature regulation in desert robber flies (Diptera: Asilidae). Ecological Entomology, 14, 419-428.

Morgan, K.R., Shelly,T. E., \& Kimsey, L.S. (1985). Body temperature regulation, energy metabolism, and wing loading in light-seeking and shade-seeking robber flies. Journal of Comparative Physiology, 155, 561-570.

Musso, J.J. (1968). Digestion extra-intestinale chez Stenopogon sabaudus F. et Machimus pilipes Meig. (Dipt. Asilidae). Bulletin de la Société Zoologique de France, 93, 487-497. 